\title{
Selectivity of pesticides registered for soybean crop on Telenomus podisi and Trissolcus basalis ${ }^{1}$
}

\author{
Ronaldo Zantedeschi' ${ }^{2}$, Anderson Dionei Grützmacher ${ }^{2}$, \\ Juliano de Bastos Pazini ${ }^{2}$, Flávio Amaral Bueno ${ }^{2}$, Larissa Longaray Machado ${ }^{2}$
}

\section{ABSTRACT}

The use of pesticides in the soybean crop may impair the biological control, if the products are not selective to Telenomus podisi and Trissolcus basalis, which are important stink bug egg parasitoids. This study aimed to assess the selectivity of 15 pesticides registered for soybean crop on adults of T. podisi and T. basalis. Three laboratory bioassays were performed, totaling 18 treatments, in a completely randomized design, with four replications. The insecticides ( $\mathrm{g}$ or $\mathrm{mL}$ of a.i.) imidacloprid + beta-cyfluthrin $(0.25+0.03)$, deltamethrin (0.06), thiamethoxam + lambda-cyhalothrin $(0.27+0.35)$, acephate (1.87) and fenitrothion (1.25) are harmful to both parasitoids species. Flubendiamide (1.20), diflubenzuron (2.00), Bacillus thuringiensis (0.08) and lufenuron (0.12) are innocuous to both parasitoids. The fungicides azoxystrobin + flutriafol $(0.31+0.31)$, trifloxystrobin + prothioconazole $(0.37+0.44)$, pyraclostrobin + metconazole $(0.33+0.12)$ and trifloxystrobin + cyproconazole $(0.94+0.40)$ are innocuous to $T$. podisi, but slightly harmful to $T$. basalis. The herbicides glufosinate ammonium salt (0.50) and glyphosate isopropylamine salt (1.20) are innocuous to both parasitoids.

KEY-WORDS: Glycine max; biological control; chemical control; integrated pest management.

\section{INTRODUCTION}

Brazil stands out among the largest pesticides consumers in the world, what brings concerns about the levels of pesticide residues above thresholds in foods, which may cause health problems to people (Vilca et al. 2017). In addition, pesticides may cause adverse effects to natural enemies, compromising their survival and the biological control of insect pests, requiring greater amounts of pesticides each year to correct the imbalance due to their intensive use (Silva \& Bueno 2015).

\section{RESUMO}

Seletividade de agrotóxicos registrados para a cultura da soja a Telenomus podisi e Trissolcus basalis

A utilização de agrotóxicos na cultura da soja pode prejudicar o controle biológico, caso os produtos não sejam seletivos a Telenomus podisi e Trissolcus basalis, que são importantes parasitoides de ovos de percevejos. Objetivou-se avaliar a seletividade de 15 agrotóxicos registrados para a cultura da soja sobre adultos de T. podisi e T. basalis. Realizaram-se três bioensaios em laboratório, totalizando 18 tratamentos, em delineamento inteiramente casualizado, com quatro repetições. Os inseticidas (g ou $\mathrm{mL}$ do i.a.) imidacloprido + beta-ciflutrina $(0,25+0,03)$, deltametrina $(0,06)$, tiametoxam + lambda-cialotrina $(0,27+0,35)$, acefato $(1,87)$ e fenitrotiona $(1,25)$ são nocivos às duas espécies de parasitoides. Flubendiamida $(1,20)$, diflubenzuron $(2,00)$, Bacillus thuringiensis $(0,08)$ e lufenuron $(0,12)$ são inócuos a ambos os parasitoides. Os fungicidas azoxistrobina + flutriafol $(0,31+0,31)$, trifloxistrobina + protioconazol $(0,37+0,44)$, pyraclostrobina + metconazol $(0,33+0,12)$ e trifloxistrobina + ciproconazol $(0,94+$ $0,40)$ são inócuos a T. podisi, mas levemente nocivos a T. basalis. Os herbicidas glufosinato sal de amônio $(0,50)$ e o glifosato sal de isopropilamina $(1,20)$ são inócuos a ambos os parasitoides.

PALAVRAS-CHAVE: Glycine max; controle biológico; controle químico; manejo integrado de pragas.

The Telenomus podisi (Ashmead 1893) and Trissolcus basalis (Wollaston 1858) (Hymenoptera: Platygastridae) egg parasitoids are important natural regulators of stink bug populations in soybean (Parra 2002). Despite their specificities, regarding the preferred host, both are found parasitizing eggs of the main soybean stink bug pests (Lopes et al. 2012). Parasitism rates reach $80 \%$ for $T$. podisi (Pacheco \& Corrêa-Ferreira 2000) and $60 \%$ for T. basalis (Corrêa-Ferreira \& Moscardi 1995). These parasitoids cause host mortality by either toxicity of substances inoculated by the female at

1. Manuscript received in Nov./2017 and accepted for publication in Mar./2018 (http://dx.doi.org/10.1590/1983-40632018v4850348).

2. Universidade Federal de Pelotas, Faculdade de Agronomia Eliseu Maciel, Departamento de Fitossanidade, Pelotas, RS, Brasil. E-mails: ronaldozantedeschi@gmail.com, adgrutzm@ufpel.edu.br, julianopazzini@hotmail.com, flavioamaralbueno@gmail.com, larissalongaray@hotmail.com. 
oviposition or by direct consumption of the host, when the parasitoid larva develops inside the egg. Both T. podisi and T. basalis have a wide geographic distribution in Brazil and are capable of parasitizing several species of phytophagous bugs, playing a natural control of the main species of these pests. Therefore, their occurrence is desirable for a balanced agro-ecosystem (Corrêa-Ferreira \& Moscardi 1995).

The use of pesticides is the most effective tactic for pest control in the Brazilian agriculture; however, the choice for a pesticide should be based on its selectivity to non-target species. Thus, the integrated pest management enables the use of chemical and biological control for a more efficient and sustainable agriculture (Ramos et al. 2017). To date, few studies in Brazil have assessed the selectivity of pesticides registered for soybean crops in egg parasitoids of hemipterans (Stecca et al. 2017). Most selectivity tests focus on egg parasitoids of lepidopterans (Carmo et al. 2009, Vieira et al. 2012, Magano et al. 2013 and 2015, Stecca et al. 2016). Thus, this study aimed to assess the selectivity of pesticides registered for soybean crop on the stink bug egg parasitoids T. podisi and T. basalis in adult stage.

\section{MATERIAL AND METHODS}

Selectivity tests with the parasitoids $T$. podisi and $T$. basalis were conducted at the Universidade
Federal de Pelotas, in Pelotas, Rio Grande do Sul state, Brazil, in 2016. An adaptation of the standardized method established by the International Organization for Biological and Integrated Control of Noxious Animals and Plants (IOBC), for egg parasitoids of lepidopterans, proposed by Peres \& Corrêa-Ferreira (2004), was used.

Eggs of the stink bug Euschistus heros (Fabricius, 1974) (Hemiptera: Pentatomidae) and parasitoids $T$. podisi and $T$. basalis from laboratory rearing, supplied by Embrapa Recursos Genéticos e Biotecnologia, were used. The parasitoids were reared in cylindrical glass tubes $(20 \mathrm{~cm} \times 10 \mathrm{~cm})$, fed with pure honey (Pazini et al. 2016) and kept in a controlled environment (temperature: $25 \pm 1{ }^{\circ} \mathrm{C}$; relative humidity: $70 \pm 10 \%$; photophase: $14 \mathrm{~h}$ ).

Three bioassays were carried out in a completely randomized design, with four replications. A total of 15 pesticides registered for soybean crop (Agrofit 2016) on adult parasitoids, using the maximum dosage for each product, were evaluated. The pesticides assessed were 9 insecticides, 4 fungicides and 2 herbicides, whose active ingredients and dosages are shown in Table 1. Each pesticide was compared with a control in which the application was made only with distilled water.

In the treatments, the commercial product was sprayed onto colorless glass plates ( $2 \mathrm{~mm}$ thick, $130 \mathrm{~mm} \times 130 \mathrm{~mm}$ in dimension). On the glass plate,

Table 1. Pesticides registered for soybean crop and tested for selectivity to adults of Telenomus podisi and Trissolcus basalis.

\begin{tabular}{|c|c|c|c|c|}
\hline Commercial product ${ }^{1 /}$ & Active ingredient & Chemical group & C.A.I. ${ }^{\prime /}$ & D.C.P. ${ }^{3 /}$ \\
\hline \multicolumn{5}{|c|}{ Insecticides } \\
\hline Belt & Flubendiamide & Diamides & 1.20 & 70 \\
\hline Connect & Imidacloprid + beta-cyfluthrin & Neonicotinoid + pyrethroid & $0.25+0.03$ & 1,000 \\
\hline Decis $25 \mathrm{EC}$ & Deltamethrin & Pyrethroid & 0.06 & 200 \\
\hline Dimilin $80 \mathrm{WG}$ & Diflubenzuron & Benzoylurea & 2.00 & 150 \\
\hline Dipel PM & Bacillus thuringiensis & Biological & 0.08 & 500 \\
\hline Engeo Pleno & Lambda-cyhalothrin + thiamethoxam & Pyrethroid + neonicotinoid & $0.35+0.27$ & 200 \\
\hline Match EC & Lufenuron & Benzoylurea & 0.12 & 150 \\
\hline Orthene 750 BR & Acephate & Organophosphorus & 1.87 & 750 \\
\hline Sumithion $500 \mathrm{EC}$ & Fenitrothione & Organophosphorus & 1.25 & 1,500 \\
\hline \multicolumn{5}{|c|}{ Fungicides } \\
\hline Authority & Azoxystrobin + flutriafol & Strobilurin + triazole & $0.31+0.31$ & 600 \\
\hline Fox & Trifloxystrobin + prothioconazole & Strobilurin + triazole & $0.37+0.44$ & 400 \\
\hline Opera Ultra & Pyraclostrobin + metconazole & Strobilurin + triazole & $0.33+0.12$ & 600 \\
\hline Sphere Max & Trifloxystrobin + cyproconazole & Strobilurin + triazole & $0.94+0.40$ & 200 \\
\hline \multicolumn{5}{|c|}{ Herbicides } \\
\hline Finale & Glufosinate ammonium salt & Homoalanine replaced & 0.50 & 2,000 \\
\hline Glyphosate Atanor & Isopropylamine salt & Glycine replaced & 1.20 & 6,000 \\
\hline
\end{tabular}


an acrylic plate of equal size was placed, but with an inside cut to allow a $100 \mathrm{~mm} \times 100 \mathrm{~mm}$ area to be hit by the spray. The product was sprayed with a $0.5 \mathrm{~L}$ manual sprayer, depositing on the plate $200 \mathrm{mg} / 100 \mathrm{~cm}^{2} \pm 10 \%$ (totaling $2 \mathrm{mg}$ of spray mix per $\mathrm{cm}^{2}$ of the plate surface $=200 \mathrm{~L} \mathrm{ha}^{-1}$ ), which was calibrated by weighing the plate on a precision scale (Holtz et al. 2014). After drying the spray mix, the plates were embedded in a steel structure $(13 \mathrm{~cm} \mathrm{x}$ $1.5 \mathrm{~cm} \times 1.0 \mathrm{~cm}$ on each side) fenced on three sides with black voile fabric to prevent parasitoids from escaping. The other side of the cage had two holes, one for inserting the tube containing the parasitoids and the other for inserting cards containing host eggs of $E$. heros. The plates were covered with a brown cardboard that allowed light inside the cage and were fixed with two clips.

The cages were transferred to an airconditioned room under the same rearing conditions of the host and parasitoids, where emergence tubes were connected (glass tubes with diameter of $10 \mathrm{~mm}$ and $100 \mathrm{~mm}$ long), containing from 45 to 50 adult parasitoids of about $24 \mathrm{~h}$ old. The adults were drawn to the inside of the cages by positive phototropism and the food consisted of a fillet of pure honey offered on a piece of aluminum foil $(1 \mathrm{~cm} \times 5 \mathrm{~cm})$ inside the cage.

After $24 \mathrm{~h}$ of the cages installation, the emergence tubes were disconnected and, in each cage, a blue card paper $(1 \mathrm{~cm} \times 5 \mathrm{~cm})$ with 50 eggs of $E$. heros was fixed with Arabic gum. The same procedure was repeated at $48 \mathrm{~h}$ and $72 \mathrm{~h}$. After $96 \mathrm{~h}$ of the bioassay setting, the cages were disassembled and each treatment card was packaged in colorless glass tubes of $8.5 \mathrm{~cm} \times 2.5 \mathrm{~cm}$ and sealed on top with voile fabric and a rubber string. These tubes were transferred to an acclimatized room under the same rearing conditions of insects until assessment.

Pesticides were classified based on parasitism reduction, in comparison with the control, and calculated by the equation: $\operatorname{PR}(\%)=[(1-\mathrm{Vt} / \mathrm{Vc}) * 100]$, where $P R$ is the percentage of parasitism reduction; $V t$ the average parasitism for the treatment; and $V c$ the average parasitism of the control. Therefore, pesticides were classified according to the IOBC standards, as it follows: class 1: innocuous (PR < $30 \%)$; class 2 : slightly harmful $(30 \% \leq \mathrm{PR}<80 \%)$; class 3: moderately harmful ( $80 \% \leq \mathrm{PR}<99 \%)$; class 4: harmful (PR $\geq 99 \%)$.

The data of average number of eggs parasitized per female were submitted to normality analysis by the Shapiro-Wilk test and variance homogeneity by the Bartlett test. When assumptions were not met, the non-parametric Kruskal-Wallis analysis was used, as well as the ranking of means by the Dunn test with Bonferroni correction. Otherwise, the variance analysis (Anova) was carried out. All tests were applied at $5 \%$ of significance.

\section{RESULTS AND DISCUSSION}

Insecticides with the active ingredients imidacloprid + beta-cyfluthrin, thiamethoxam + lambda-cyhalothrin, acephate, deltamethrin and fenitrothione differed significantly from the control, regarding the number of eggs/female parasitized. These treatments caused $100 \%$ of parasitism reduction and, therefore, were classified as harmful (class 4) for both parasitoids (Table 2).

The mixture of insecticides of the neonicotinoid group with the pyrethroid group, as in the formulations imidacloprid + beta-cyfluthrin and thiamethoxam +

Table 2. Parasitism reduction and classification of neurotoxic insecticides registered for soybean crop to Telenomus podisi and Trissolcus basalis - Bioassay I (temperature: $25 \pm 1{ }^{\circ} \mathrm{C}$; RH: $70 \pm 10 \%$; photophase: $14 \mathrm{~h}$ ).

\begin{tabular}{|c|c|c|c|c|c|c|}
\hline \multirow{2}{*}{ Treatment } & \multicolumn{3}{|c|}{ Telenomus podisi } & \multicolumn{3}{|c|}{ Trissolcus basalis } \\
\hline & Eggs/female $(\bar{x} \pm \mathrm{SE})^{1 /}$ & P.R. ${ }^{2 /}$ & C..$^{3 /}$ & Eggs/female $(\bar{x} \pm \mathrm{SE})^{1 /}$ & P.R. ${ }^{2 /}$ & $\mathrm{C}^{3 /}$ \\
\hline Imidacloprid + beta-cyfluthrin & $0.00 \pm 0.00 \mathrm{~b}^{*}$ & 100 & 4 & $0.00 \pm 0.00 \mathrm{~b}^{*}$ & 100 & 4 \\
\hline Lambda-cyhalothrin + thiamethoxam & $0.00 \pm 0.00 \mathrm{~b}$ & 100 & 4 & $0.00 \pm 0.00 \mathrm{~b}$ & 100 & 4 \\
\hline Acephate & $0.00 \pm 0.00 \mathrm{~b}$ & 100 & 4 & $0.00 \pm 0.00 \mathrm{~b}$ & 100 & 4 \\
\hline Deltamethrin & $0.00 \pm 0.00 \mathrm{~b}$ & 100 & 4 & $0.00 \pm 0.00 \mathrm{~b}$ & 100 & 4 \\
\hline Fenitrothione & $0.00 \pm 0.00 \mathrm{~b}$ & 100 & 4 & $0.00 \pm 0.00 \mathrm{~b}$ & 100 & 4 \\
\hline Control & $3.57 \pm 0.09 \mathrm{a}$ & - & - & $13.30 \pm 0.73 \mathrm{a}$ & - & - \\
\hline
\end{tabular}

${ }^{1 /}$ Mean \pm standard error of parasitized eggs per female in each treatment, after $96 \mathrm{~h}$ of exposure of parasitoids to pesticide residues. * Results of the Kruskal-Wallis test $(\mathrm{p}=0.0002 ; \mathrm{H}=22.763$ and $\mathrm{p}=0.0003 ; \mathrm{H}=22.763$, respectively for $T$. podisi and T. basalis), followed by the Dunn test with Bonferroni correction ( $\mathrm{p}<0.05$ ). ${ }^{2 /}$ Parasitism reduction, in comparison with the control. ${ }^{3 /}$ IOBC classes: $1=$ innocuous $(\mathrm{PR}<30 \%) ; 2=$ slightly harmful $(30 \% \leq \mathrm{PR}<80 \%) ; 3=$ moderately harmful $(80 \% \leq \mathrm{PR}<99 \%) ; 4=$ harmful (PR $\geq 99 \%)$. Means followed by the same letter do not differ significantly by the Dunn test. 
lambda-cyhalothrin, is reported in the literature as harmful to Trichogramma pretiosum (Riley 1879) (Hymenoptera: Trichogrammatidae), in laboratory tests (Moura et al. 2004). These insecticides act immediately by "shock effect" caused by pyrethroids, as well as by the effect provided by neonicotinoids acting systemically in the plant tissue.

Pazini et al. (2016) concluded that this combination of chemical groups of insecticides have a deleterious effect on species of egg parasitoids such as T. podisi and T. pretiosum. Turchen et al. (2015) also observed a rapid mortality caused by lambdacyhalothrin + thiamethoxam to T. podisi, in direct exposure tests in laboratory. Both the researches assessed the same doses of the insecticide evaluated in the present study.

Insecticides of the organophosphorus chemical group, which act by inhibiting an important neurotransmitter, acetylcholinesterase (AChE), have a low molecular weight, which possibly increases its toxicity by favoring the penetration of the molecule insecticide into the insect cuticle (Fukuto 1990). This feature confers these insecticides a broad spectrum of activity, compromising the survival of parasitoids, as observed by Bastos et al. (2006) with monocrotophos and metamidophos insecticide, which reduced the parasitism of $T$. pretiosum by more than $95 \%$.

Suh et al. (2000) also proved the harmful activity of profenophos to Trichogramma exiguum (Pinto \& Platner 1978) (Hymenoptera: Trichogrammatidae), in laboratory tests. Vieira et al. (2001) also reported the harmful effect of organophosphorus trichlorfon to adult Trichogramma cordubensis (Vargas \& Cabello 1985) (Hymenoptera: Trichogrammatidae). In their study, the exposure to the pesticide caused a mortality rate of more than $94 \%$ of the parasitoids in the first
$24 \mathrm{~h}$ of contact with residual insecticide. Although the active ingredients of organophosphorus insecticides in this study differ from those in the studies presented, the fact that they belong to the same chemical group confers them a low selectivity.

The active ingredients diflubenzuron, flubendiamide and lufenuron and the biological insecticide Bacillus thuringiensis did not differ significantly from the control to both parasitoids. Hence, they were classified as innocuous (class 1), with less than $10 \%$ of parasitism reduction (Table 3). Although the average number of parasitized eggs per T. basalis female was low in this bioassay, if compared to the others, the results were validated, because it was a characteristic of the parasitoid strain and did not interfere in the selectivity test.

Insecticides that act as insect growth regulators, such as diflubenzuron and lufenuron (Table 3), act after ingestion and do not normally affect adults of egg parasitoids (Bastos et al. 2006). The insecticides actions are attributed to the inhibition of chitin synthesis in the insect integument, leading to its death by a malformation of the exoskeleton (Tunaz \& Uygun 2004). Thus, insecticides belonging to this group tend to be more specific, because they act exclusively on immature stages of insects, with reduced impact on adult hymenopterans that are egg parasitoids (Dhadialla et al. 1998).

The selectivity of diflubenzuron to T. podisi was confirmed by Pazini et al. (2016) and to T. remus by Carmo et al. (2009), when both parasitoids were exposed to direct contact with the pesticide. Lufenuron was classified as innocuous to T. podisi by Stecca et al. (2017) and to Trichogramma chilonis (Ishii 1941) (Hymenoptera: Trichogrammatidae) by Sattar et al. (2011). In these studies, the parasitoids

Table 3. Parasitism reduction and classification of growth regulator insecticides and biological insecticides registered for soybean crop to Telenomus podisi and Trissolcus basalis - Bioassay II (Temperature: $25 \pm 1{ }^{\circ} \mathrm{C}$; RH: $70 \pm 10 \%$; photophase: $14 \mathrm{~h}$ ).

\begin{tabular}{|c|c|c|c|c|c|c|}
\hline \multirow{2}{*}{ Treatment } & \multicolumn{3}{|c|}{ Telenomus podisi } & \multicolumn{3}{|c|}{ Trissolcus basalis } \\
\hline & Eggs/female $(\bar{x} \pm \mathrm{SE})^{1 /}$ & P.R. ${ }^{2 /}$ & $\mathrm{C}^{3 /}$ & Eggs/female $(\bar{x} \pm \mathrm{SE})^{1 /}$ & P.R. ${ }^{2 /}$ & $\mathrm{C}^{3 /}$ \\
\hline Diflubenzuron & $5.44 \pm 0.88^{\mathrm{ns}}$ & 0.00 & 1 & $4.72 \pm 1.77^{\mathrm{ns}}$ & 0.00 & 1 \\
\hline Flubendiamide & $5.12 \pm 0.78$ & 0.00 & 1 & $3.51 \pm 0.58$ & 9.39 & 1 \\
\hline Bacillus thuringiensis & $4.95 \pm 0.24$ & 0.00 & 1 & $6.18 \pm 2.15$ & 0.00 & 1 \\
\hline Lufenuron & $4.38 \pm 0.57$ & 9.75 & 1 & $3.62 \pm 0.39$ & 6.61 & 1 \\
\hline Control & $4.85 \pm 0.10$ & - & - & $3.87 \pm 2.52$ & - & - \\
\hline
\end{tabular}

${ }^{1 /}$ Mean \pm standard error of parasitized eggs per female in each treatment, after $96 \mathrm{~h}$ of exposure of parasitoids to pesticide residues. ${ }^{\mathrm{ns}}$ Not significant by the variance analysis $(\mathrm{F}=0.795)$ to $T$. podisi and by the Kruskal-Wallis test $(\mathrm{p}=0.612)$ to $T$. basalis. ${ }^{2 /}$ Parasitism reduction, in comparison with the control. ${ }^{3 /}$ IOBC classes: $1=$ innocuous $(\mathrm{PR}<30 \%) ; 2=$ slightly harmful $(30 \% \leq \mathrm{PR}<80 \%) ; 3=$ moderately harmful $(80 \% \leq \mathrm{PR}<99 \%) ; 4=$ harmful $(\mathrm{PR} \geq 99 \%)$. 
mortality was not significant, in comparison with the control treatment, in laboratory selectivity tests.

Vianna et al. (2009) classified lufenuron as harmless to two strains of T. pretiosum, after exposing the parasitoids to the spraying of the pesticide on eggs of the alternative host Anagasta kuehniella (Zeller 1879) (Lepidoptera: Pyralidae).

The action of the diamides chemical group insecticides activates ryanodine receptors in insects. These receptors play a fundamental role in the insect musculature, and the uncontrolled calcium release in the sarcoplasmic reticulum provoked by insecticides of this group causes a permanent paralysis that tends to lead to the death of the contaminated insect (Cordova et al. 2006). The results of the present study show that the active ingredient flubendiamide is innocuous to T. podisi and T. basalis (Table 3). Pazini et al. (2016) also proved the harmlessness of this insecticide to the egg parasitoids $T$. podisi and $T$. pretiosum, which did not have the parasitism affected by contact with the pesticide dry residue. This active ingredient was also innocuous to T. chilonis, characterized as little persistent and with a low potential to change the parasitism rate, despite causing a mortality rate of about $31 \%$ to the parasitoids (Sattar et al. 2011).

The biological insecticide $B$. thuringiensis has a fast action against pests of the Lepidoptera order and is a control agent that should be used in integrated pest management (Polanczyk \& Alves 2003). The selectivity of this commercial product is due to the high specificity of the insecticide proteins to Lepidoptera, Coleoptera and Diptera, not affecting Hymenoptera egg parasitoids (Praça et al. 2004). Adults of $T$. pretiosum also did not show a parasitism reduction in contact with $B$. thuringiensis in laboratory, demonstrating the harmlessness of the product to non-target species (Silva \& Bueno 2015).

Fungicides containing pyraclostrobin + metconazole, trifloxystrobin + cyproconazole, azoxystrobin + flutriafol and trifloxystrobin + protioconazol did not differ statistically from the control, and were innocuous (class 1) to T. podisi. However, they were slightly harmful (class 2) to T. basalis, differing statistically from the control $(\mathrm{p}<0.05)$, except for trifloxystrobin + protioconazol, which, despite no statistical difference, reduced the parasitism by $33.62 \%$, being classified as slightly harmful (class 2) (Table 4). The desiccant herbicides glufosinate ammonium salt and glyphosate isopropylamine salt did not differ statistically from the control ( $p>0.05)$, being classified as harmless to both parasitoid species.

Pazini et al. (2016) classified fungicides containing the active ingredients trifloxystrobin + protioconazole as innocuous to $T$. podisi, in agreement with the results in this study (Table 4). However, Magano et al. (2015) classified trifloxystrobin + protioconazole as slightly harmful to T. pretiosum in laboratory tests, showing that this fungicide is slightly harmful to some parasitoid species. The authors also classified pyraclostrobin + epoxiconazole and trifloxystrobin + cyproconazole as moderately harmful, once again proving that mixtures of triazole and strobilurins have bad effects on the parasitoid species.

The chemical group of triazole in mixture with the group of strobilurins is used in the formulation of many fungicides, because they combine the

Table 4. Parasitism reduction and classification of fungicides and herbicides registered for soybean crop to Telenomus podisi and Trissolcus basalis - Bioassay III (temperature: $25 \pm 1{ }^{\circ} \mathrm{C}$; RH: $70 \pm 10 \%$; photophase: $14 \mathrm{~h}$ ).

\begin{tabular}{|c|c|c|c|c|c|c|}
\hline \multirow{2}{*}{ Treatment } & \multicolumn{3}{|c|}{ Telenomus podisi } & \multicolumn{3}{|c|}{ Trissolcus basalis } \\
\hline & Eggs/female $(\bar{x} \pm \mathrm{SE})^{1 /}$ & P.R. ${ }^{2 /}$ & C. ${ }^{3 /}$ & Eggs/female $(\bar{x} \pm \mathrm{SE})^{1 /}$ & P.R. $^{2 /}$ & C. ${ }^{3 /}$ \\
\hline Pyraclostrobin + metconazole & $4.35 \pm 0.24^{\mathrm{ns}}$ & 3.61 & 1 & $4.46 \pm 0.99 \mathrm{~b}^{*}$ & 63.56 & 2 \\
\hline Trifloxystrobin + cyproconazole & $3.64 \pm 0.48$ & 0.00 & 1 & $4.93 \pm 0.64 \mathrm{~b}$ & 59.30 & 2 \\
\hline Azoxystrobin + flutriafol & $4.77 \pm 0.10$ & 0.00 & 1 & $3.40 \pm 0.29 \mathrm{~b}$ & 71.87 & 2 \\
\hline Trifloxystrobin + prothioconazole & $4.24 \pm 0.88$ & 6.07 & 1 & $8.03 \pm 2.19 \mathrm{ab}$ & 33.62 & 2 \\
\hline Glufosinate ammonium salt & $3.88 \pm 0.57$ & 13.95 & 1 & $10.18 \pm 0.55 \mathrm{a}$ & 15.79 & 1 \\
\hline Isopropylamine salt & $3.86 \pm 0.78$ & 14.42 & 1 & $9.42 \pm 0.90 \mathrm{ab}$ & 25.81 & 1 \\
\hline Control & $4.51 \pm 0.31$ & - & - & $12.10 \pm 0.08 \mathrm{a}$ & - & - \\
\hline
\end{tabular}

${ }^{1 /}$ Mean \pm standard error of parasitized eggs per female in each treatment, after $96 \mathrm{~h}$ of exposure of parasitoids to pesticide residues. ${ }^{\text {ns }}$ Not significant by the variance analysis $(\mathrm{F}=0.417) .{ }^{*}$ Results of the Kruskal-Wallis test $(\mathrm{p}=0.0052 ; \mathrm{H}=18.431)$ followed by the Dunn test with Bonferroni correction $(\mathrm{p}<0.05) .{ }^{2 /}$ Parasitism reduction, in comparison with the control. ${ }^{3 /} \mathrm{IOBC}$ classes: $1=$ innocuous $(\mathrm{PR}<30 \%) ; 2=$ slightly harmful $(30 \% \leq \mathrm{PR}<80 \%) ; 3=$ moderately harmful $(80 \% \leq \mathrm{PR}<99 \%) ; 4=$ harmful (PR $\geq 99 \%)$. Means followed by the same letter do not differ significantly by the Dunn test. 
curative power of triazole added to the residual effect provided by strobilurins (Pimenta et al. 2011). Although fungicides focus their actions on fungi, toxicity comes from their formulation with ingredients sometimes toxic and with differentiated selectivity to each parasitoid species (Carvalho et al. 2012).

The major share of herbicide glyphosate on the world market is attributed to its broad spectrum of action and the advent of soybean cultivars resistant to this herbicide molecule (Shaner 2000). Stecca et al. (2016) classified the glyphosate isopropylamine salt as selective to T. remus, when adult parasitoids were exposed to the pesticide applied on glass plates, highlighting its differentiated selectivity to parasitoid species.

Desiccant herbicides are usually selective to egg parasitoids, such as Palmistichus elaeisis (Delvare \& La Salle 1993) (Hymenoptera: Eulophidae), which was not affected by the ammonium salt-based desiccant. However, the impact of desiccant herbicides must be studied in other developmental phases of parasitoids for a better understanding of their impact on non-target species (Hassan \& Abdelgader 2001).

The results of this research show that the parasitoid T. basalis is more susceptible to some pesticides in its adult stage, such as fungicides (Table 4), if compared to T. podisi. This may influence the predominance between one or another species in the field. This study was conducted with parasitoid lineages coming from the Brazilian midwest, and assays were carried out with species from other regions of the country. Thus, tests with lineages derived from southern Brazil are also necessary for a more accurate conclusion about the selectivity to T. podisi and T. basalis in this region.

Neurotoxic insecticides should be avoided, since they were not selective to parasitoids. The group of diamides, insect growth regulators and biological insecticides should be preferred whenever possible, as they are selective to the two parasitoid species tested here. Triazole-based fungicides combined with strobilurins were not selective to $T$. basalis, although semi-field and field tests are needed for a better understanding of their impact under these conditions. Other pest control methods, such as transgenic plants, do not have an effect on Hemipterans yet; thus, the use of pesticides selective to parasitoids of stink bug eggs is of great importance to the integrated pest management application in the soybean crop.

\section{CONCLUSIONS}

1. The neurotoxic insecticides imidacloprid + betacyfluthrin, thiamethoxam + lambda-cyhalothrin, acephate, deltamethrin and fenitrothione are not selective to T. podisi and T. basalis, but the insecticides diflubenzuron, flubendiamide, Bacillus thuringiensis and lufenuron are selective to both parasitoids;

2. Fungicides formulated with pyraclostrobin + metconazole, trifloxystrobin + cyproconazole, azoxystrobin + flutriafol and trifloxystrobin + protioconazol are selective to $T$. podisi, but not to T. basalis;

3. Herbicides containing glufosinate ammonium salt and isopropylamine salt are selective to the egg parasitoids T. podisi and T. basalis.

\section{REFERENCES}

AGROFIT: sistema de agrotóxicos fitossanitários. 2016. Available at: <http://agrofit.agricultura.gov.br/agrofit cons/principal_agrofit_cons $>$. Access on: 21 Jan. 2016.

BASTOS, C. S. et al. Selectivity of pesticides used on cotton (Gossypium hirsutum) to Trichogramma pretiosum reared on two laboratory-reared hosts. Pest Management Science, v. 62, n. 1, p. 91-98, 2006.

CARMO, E. L. et al. Seletividade de diferentes agrotóxicos usados na cultura da soja ao parasitoide de ovos Telenomus remus. Ciência Rural, v. 39, n. 8, p. 2293-2300, 2009.

CARVALHO, J. R. et al. Seletividade de fungicidas utilizados na cultura do tomateiro (Lycopersicum esculentum, MILL.) a Trichogramma pretiosum. Nucleus, v. 9, n. 2, p. 177-185, 2012.

CORDOVA, D. et al. Anthranilic diamides: a new class of insecticides with a novel mode of action, ryanodine receptor activation. Pesticide Biochemistry Physiology, v. 84, n. 1, p. 196-214, 2006.

CORREAA-FERREIRA, B. S.; MOSCARDI, F. Seasonal occurrence and host spectrum of egg parasitoids associated with soybean stink bugs. Biological Control, v. 5, n. 2, p. 196-202, 1995.

DHADIALLA, T. S. et al. New insecticides with ecdysteroidal and juvenile hormone activity. Annual Review of Entomology, v. 43, n. 1, p. 545-569, 1998.

FUKUTO, T. R. Mechanism of action of organophosphorus and carbamate insecticides. Environmental Health Perspectives, v. 87, n. 1, p. 245-254, 1990.

HASSAN, S. A.; ABDELGADER, H. A sequential testing program to assess the effects of pesticides on Trichogramma 
cacoeciae Marchal (Hym., Trichogrammatidae). IOBC/ WPRS Bulletin, v. 24, n. 4, p. 71-81, 2001.

HOLTZ, V. et al. Deposição de calda de pulverização e produtividade da soja cultivada em diferentes arranjos espaciais. Ciência Rural, v. 44, n. 8, p. 1371-1376, 2014.

LOPES, A. P. S. et al. Defesas induzidas por herbivoria e interações específicas no sistema tritrófico soja-percevejos-parasitoides de ovos. Pesquisa Agropecuária Brasileira, v. 47, n. 6, p. 875-878, 2012.

MAGANO et al. Efeitos secundários de herbicidas aplicados em soja sobre Trichogramma pretiosum. Pesquisa Agropecuária Gaúcha, v. 19, n. 2, p. 49-56, 2013.

MAGANO, D. A. et al. Evaluating the selectivity of registered fungicides for soybean against Trichogramma pretiosum Riley, 1879 (Hymenoptera: Trichogrammatidae). African Journal of Agricultural Research, v. 10, n. 40, p. 3825-3831, 2015.

MOURA, A. P. et al. Efeito residual de novos inseticidas utilizados na cultura do tomateiro sobre Trichogramma pretiosum Riley, 1879 (Hymenoptera: Trichogrammatidae). Acta Scientiarum Agronomy, v. 26, n. 2, p. 231-237, 2004.

PACHECO, D. J. P.; CORRÊA-FERREIRA, B. S. Parasitismo de Telenomus podisi Ashmead (Hymenoptera: Scelionidae) em populações de percevejos pragas da soja. Anais da Sociedade Entomológica do Brasil, v. 29, n. 2, p. 295-302, 2000.

PARRA, J. R. P. Criação massal de inimigos naturais. In: PARRA, J. R. P. et al. Controle biológico no Brasil: parasitoides e predadores. São Paulo: Manole, 2002. p. 143-161.

PAZINI, J. de B. et al. Selectivity of pesticides used in rice crop on Telenomus podisi and Trichogramma pretiosum. Pesquisa Agropecuária Tropical, v. 46, n. 3, p. 327-335, 2016.

PERES, W. A. A.; CORRÊA-FERREIRA, B. S. Methodology of mass multiplication of Telenomus podisi Ash. and Trissolcus basalis (Woll.) (Hymenoptera: Scelionidae) on eggs of Euschistus heros (Fab.) (Hemiptera: Pentatomidae). Neotropical Entomology, v. 33, n. 4, p. 457$462,2004$.

PIMENTA, C. B. et al. Efeito do tratamento de semente com fungicidas associado à pulverização foliar no controle da ferrugem asiática da soja. Summa Phytopathology, v. 37, n. 4, p. 187-193, 2011.

POLANCZYK, R.; ALVES, S. Bacillus thuringiensis: uma breve revisão. Agrociência, v. 7, n. 2, p. 1-10, 2003.

PRAÇA, L. B. et al. Estirpes de Bacillus thuringiensis efetivas contra insetos das ordens Lepidoptera, Coleoptera e Diptera. Pesquisa Agropecuária Brasileira, v. 39, n. 1, p. 11-16, 2004.

RAMOS, R. S. et al. Investigation of the lethal and behavioral effects of commercial insecticides on the parasitoid wasp Copidosoma truncatellum. Chemosphere, v. 191, n. 1, p. 770-778, 2017.

SATTAR, S. et al. Toxicity of some new insecticides against Trichogramma chilonis (Hymenoptera: Trichogrammatidae) under laboratory and extended laboratory conditions. Pakistan Journal of Zoology, v. 43, n. 6, p. 1117-1125, 2011.

SHANER, D. L. The impact of glyphosate-tolerant crops on the use of other herbicides and on resistance management. Pest Management Science, v. 56, n. 4, p. 320-326, 2000.

SILVA, D. M. da; BUENO, A. de F. Organic products selectivity for Trichogramma pretiosum (Hymenoptera: Trichogrammatidae). Agricultural Entomology, v. 20, n. 1, p. 1-8, 2015.

STECCA, C. S. et al. Impact of insecticides used in soybean crops to the egg parasitoid Telenomus podisi (Hymenoptera: Platygastridae). Neotropical Entomology, v. 46, n. 3, p. 1-11, 2017.

STECCA, C. S. et al. Side-effects of glyphosate to the parasitoid Telenomus remus Nixon (Hymenoptera: Platygastridae). Neotropical Entomology, v. 45, n. 2, p. 1-9, 2016.

SUH, C. P. C. et al. Effect of insecticides on Trichogramma exiguum (Trichogrammatidae: Hymenoptera) preimaginal development and adult survival. Biological and Microbial Control, v. 93, n. 3, p. 577-583, 2000.

TUNAZ, H.; UYGUN, N. Insect growth regulators for insect pest control. Turkish Journal of Agriculture and Forestry, v. 28, n. 1, p. 377-387, 2004.

TURCHEN, L. M. et al. Lethal and sublethal effects of insecticides on the egg parasitoid Telenomus podisi (Hymenoptera: Platygastridae). Journal of Economic Entomology, v. 109, n. 1, p. 84-92, 2015.

VIANNA, U. R. et al. Insecticide toxicity to Trichogramma pretiosum (Hymenoptera: Trichogrammatidae) females and effect on descendant generation. Ecotoxicology, v. 18, n. 1, p. 180-186, 2009.

VIEIRA, A. et al. Effects of conventional pesticides on the preimaginal developmental stages and on adults of Trichogramma cordubensis (Hymenoptera: Trichogrammatidae). Biocontrol Science and Technology, v. 11, n. 1 , p. $527-534,2001$.

VIEIRA, S. S. et al. Efeitos dos inseticidas utilizados no controle de Bemisia tabaci (Gennadius) biótipo B e sua seletividade aos inimigos naturais na cultura da soja. Ciências Agrárias, v. 33, n. 5, p. 1809-1818, 2012.

VILCA, F. Z. et al. Análise de resíduos de agrotóxicos organoclorados em morango usando o método QuEChERS com CG- $\mu \mathrm{ECD}$. Revista de Investigaciones Altoandinas, v. 19, n. 1, p. 5-10, 2017. 